\title{
Determining the Factors of Teaching Effectiveness for Physical Education
}

\author{
Aungkana Boonsem ${ }^{1} \&$ Thongchai Chaoensupmanee ${ }^{1}$ \\ ${ }^{1}$ School of Liberal Arts , King Mongkut's University of Technology Thonburi, Bangkok, Thailand \\ Correspondence: Aungkana Boonsem, School of Liberal Arts, King Mongkut's University of Technology \\ Thonburi, Bangkok, Thailand.
}

Received: November 26, 2019

Accepted: December 30, 2019

Online Published: February 18, 2020

doi:10.5539/ies.v13n3p43

URL: https://doi.org/10.5539/ies.v13n3p43

\begin{abstract}
The development and maintenance of a physically active lifestyle and the promotion of health-related physical fitness have become two important components of the national standards for physical education. Physical education is one of the important aspects of the educational and teaching processes. This study was designed to determine the factors of teaching effectiveness for physical education by comparing the opinions of students on teaching courses of King Mongkut's University of Technology, Thonburi with the totals of six aspects: (1) the purposes of Physical Education learning; (2) content and Physical Education programs; (3) teaching methods and teaching activities; (4) the personality aspects of Physical Education instructors; (5) equipment and facilities; and (6) assessment and evaluation. The sample included 1,000 students, with 558 male students and 442 female students, selected using the stratified random sampling method and divided into groups based on gender and types of sports. The results of the study showed that the highest percentage for the overall development of teaching physical education were the personalities of Physical Education instructors $(59.18 \%)$ and the lowest percentage for measurement and evaluation had the lowest percentage (45.53\%). The comparison between male and female students found that the course content and curriculum were at a minimal percentage for male students $(45.42 \%)$, while the teaching methods and activities for female students (46.81\%). Physical education specialists served as an important force in providing health-enhancing physical education for children and adolescents, as they are more effective than classroom teachers in promoting moderate to vigorous physical activity.
\end{abstract}

Keywords: physical education, students, factors, teaching effectiveness

\section{Introduction}

Thailand has determined that Physical Education (PE) is an important subject for university students. The National Sports Development Plan (NSDP) Number Six (2017-2021) promoted the idea that everyone in the whole country should exercise regularly, especially the promotion of knowledge and the awareness of exercise and basic sports and encouraging people to exercise and participate in sports activities (National Sports Development Plan [NSDP], 2017-2021). Education plays an important role in a society and national development (Poonsri, 2008). The development and maintenance of a physically active lifestyle and the promotion of health-related physical fitness have become two of the most important components of the national standards for physical education. The health benefits of regularly participating in physical activities, including disease prevention and the enhancement of their quality of life.

As a result, physical education is one of the important aspects of the educational and teaching processes, especially in the current era, in which high values are placed on physical activity, as it has many positive effects on the individual. Physical education programs prepare children and adolescents for lifelong active lifestyles and the good physical healthcare endorsed in public schools (Sallis, McKenzie, Beets, Beighle, Erwin, \& Lee, 2012; Lohaphaiboonkun, 2011). Physical education is provided in the school curriculum from the elementary to the university. The National Higher Education Qualifications Framework 2009 (TQF: HEd) and the standard criteria for undergraduate courses (2015) stated that "subjects that enhance human integrity to be knowledgeable, widely understood and valued for themselves, others, society, arts, culture and nature" (Office of the Higher Education commission, 2006). General Education divides the learning outcomes of general education courses into eight categories, one of which is about "having knowledge and understanding of the promotion of physical and mental health". Higher education has organized compulsory Physical Education courses in the curriculum (Sinlarat, 
Theerapijit, \& Chaodamrong, 2009).

In KMUTT, physical education assigned students to various courses and they must study thirty-one credits of General Education courses including health, integration and language. Physical Education is a formal content area of study in schools that is standards-based and encompasses assessments based on standards and benchmarks. It is defined as a planned sequential standards-based program of curricula and instruction designed to develop the students in terms of motor skills, knowledge, behaviors of healthy and active living, physical fitness, sportsmanship, self-efficacy, and emotional intelligence." As a school subject, physical education is focused on teaching school-aged children the science and methodology of physically active and healthy living (National Association for Sport and Physical Education [NASPE], 2012). It is an avenue for engaging in developmentally appropriate physical activities designed for children to develop their fitness, gross motor skills, and health (Robinson \& Goodway, 2009).

Sports activities in schools are considered to be the spine of the education and cultivation of students through the various cultural and recreational activities. These sports activities encourage investing the leisure time and appreciating the factors of responsibility, respecting themselves and others, and developing the ability to make the right decisions. School sport is an educational and economic system that pumps cadres of young people for competitive sports and opening the international market (Oudat, Bader, \& Khasawneh, 2009).

Over the years the physical condition of university students has become worrying and a serious problem for higher education and a hot issue for social concern. The innovation of the university curriculum management system has become an important means to reform current teaching management system to improve the quality of university courses. In terms of education, the student voice refers to the values, opinions, beliefs, perspectives, and cultural backgrounds of individual students and groups of students. It also applies to instructional approaches and the techniques based on student choices, interests, passions, and ambitions. The purpose of this study is to identify and correlate the factors affecting teaching effectiveness for Physical Education and to determine the direct relationships between identifying factors and the opinions of the students. This study will contribute to unraveling the significant determinants on student performance that need to be addressed. It also served as a guide for future physical educators for the improvement of the quality of physical education programs. In addition, the results also functioned as a platform for the university to initiate discussions on possible causal factors and how the school may address these problems so that academic performance may be improved.

\section{Method}

\subsection{Participants}

\subsubsection{Population and Sample Group}

The population consisted of 11,917 undergraduate students who were enrolled in KMUTT.

The sample from KMUTT, with 1,000 students, comprised of 558 male students and 442 female students, selected using stratified random sampling method and divided into groups based on gender and sports types.

\subsection{Study Variables}

The initial variables include the following:

1) Gender: male and female.

2) Sports types: Badminton, Table tennis, Movement, Dancing, Tennis, and Basketball.

The dependent variable is the opinions of university students with regard to the teaching of physical education.

\subsection{Procedure}

\subsubsection{Research Tools}

This research is the survey research type. The instrument is a questionnaire on the opinions of students at KMUTT and can be divided into two parts, as follows:

Part 1: The status of the respondents consisted of a check list

Part 2: Is a questionnaire on the opinions of KMUTT students. There are five levels of physical education teaching, including the highest, the most, the medium, the least, and the six aspects: the purpose of Physical Education learning, the content of Physical Education programs, teaching methods and activities, the personality aspects of Physical Education instructors, equipment and facilities, and assessment and evaluation procedures.

\subsection{Data Collection and Analysis}

In terms of data collection of the samples, the researcher conducted the following procedures: 
1) To use the questionnaire to collect data from the samples

2) To collect questionnaires to be analyzed with statistical methods

\subsection{Statistical Analysis}

In this research, the researcher analyzed the data using the SPSS for Windows program with the received questionnaire for analysis, as follows:

1) Check the completeness of the questionnaire.

2) Find the frequency and percentage of the status of the behavioral assessor

3) The data were collected using a questionnaire and analyzed using frequency (f) and percentage (\%), Mean ( $\bar{x}$ ) and standard deviation (S.D.)

\section{Results}

The research results and the opinions of KMUTT King Mongkut's University of Technology Thonburi students have towards teaching and learning physical education were as follows:

1) The opinions of KMUTT towards teaching Physical Education as a whole with the highest percentage including the purpose of Physical Education were appropriate at the very good level of 48.68 percent. The subject matter and curriculum in Physical Education was suitable at good level at 46.33 percent. Teaching methods and teaching activities were also suitable at good level of 46.02 percent. The personality of physical education instructors was appropriate at the very good level of 59.18 percent. The materials, equipment and facilities were also suitable at good level of 48.99 percent. The measurement and evaluation were both suitable at good level of 45.53 percent, with the details of opinions in each area (see Figure 1).

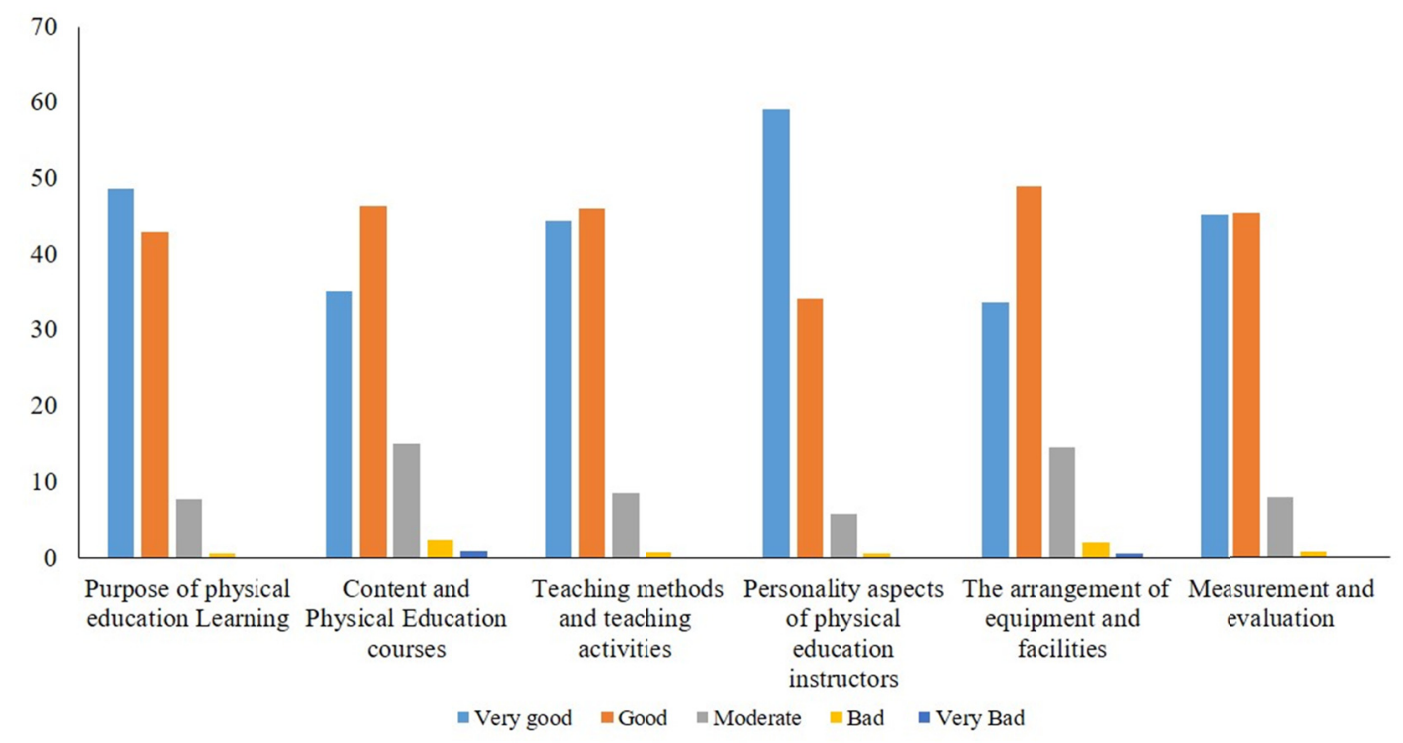

Figure 1. Teaching and learning of physical education

2) With regard to the opinions of the male KMUTT students, the teaching and learning physical education as a whole percentage were shown. The purpose of physical education was appropriate at the very good level of 49.92 percent. The course content and curriculum were appropriated at good level of 45.42 percent. The teaching methods and activities were appropriated at the very good level of 45.93 percent. The personality of Physical Education instructors was appropriate at the very good level of 58.66 percent. The factors of materials, equipment and facilities were appropriate at good level of 47.04 percent and measurement and evaluation was appropriate at the highest level at 46.70 percent (see Figure 2a).

3) The opinions of female KMUTT towards teaching and learning Physical Education as a whole percentage revealed that the purpose of Physical Education was appropriate at the very good level of 50.30 percent. The subject matter and the curriculum for Physical Education were appropriate at good level of 47.17 percent and teaching methods and activities were appropriate at the very good level of 46.81 percent. The personalities of 
Physical Education instructors were also appropriate at the very good level of 62.33 percent. The factors of materials, equipment and facilities were appropriate at good level of 51.47 percent and measurement and evaluation was appropriate at good level of 47.54 percent (see Figure 2b).

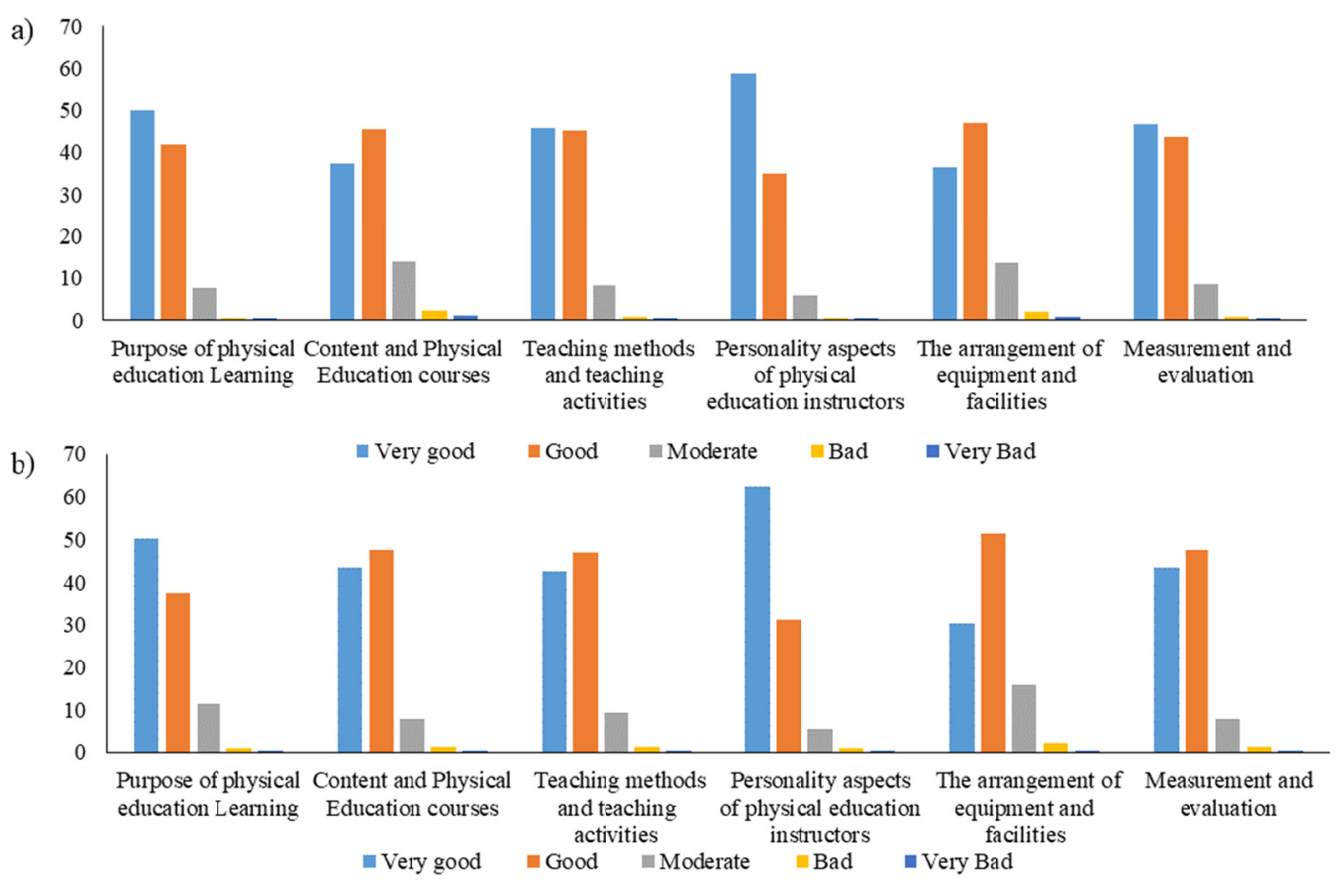

Figure 2. Teaching and learning of physical education; a) male and b) female

4) The opinions of KMUTT students towards teaching Physical Education in terms of the sport of badminton sport in general demonstrated that the purpose of Physical Education was appropriate at the very good level of 48.28 percent and the subject matter and curriculum of Physical Education was appropriate at good level of 46.29 percent. The aspect of teaching methods and the organization of teaching and learning activities was appropriate at good level of 44.70 percent. The personalities of Physical Education instructors were appropriate at the very good level of 60.62 percent. The factors of materials, equipment, and facilities was appropriate at good level of 46.20 percent and measurement and evaluation was appropriate at the very good level of 47.81 percent (see Figure 3a).

5) The opinions of KMUTT students towards Physical Education teaching of table tennis in general revealed that the purpose of Physical Education was appropriate at the very good level of 50.57 percent. The course content and curriculum are appropriate at good level of 47.43 percent and the teaching methods and learning activities were appropriate at the very good level of 49.99 percent. The personality of physical education instructors was at the very good level at 61.90 percent. The materials, equipment, and facilities were all appropriate at good level at 47.98 percent and the evaluation criteria were appropriate at the very good level of 52.41 percent (see Figure 3b).

6) The opinions of students at King Mongkut's University of Technology Thonburi towards teaching and learning Physical Education in dance sports overall and in terms of the purpose of Physical Education, which was appropriate at good level of 47.79 percent and the content and physical education courses is appropriate at good level of 48.88 percent. The teaching methods and activities were appropriate at the very good level at 52.48 percent while the personalities of Physical Education instructors were appropriate at the very good level of 53.41 percent. The arrangement of materials, equipment and facilities were appropriate at good level of 52.60 percent and the measurement and evaluation criteria were appropriate at the very good level at 51.94 percent (see Figure 3c).

7) The opinions of KMUTT students towards teaching and learning Physical Education in the sport of tennis in general, the purpose of physical education was appropriate at the very good level of 52.83 percent. The subject matter and curriculum for Physical Education was appropriate at good level of 44.15 percent and the teaching methods and teaching and learning activities was appropriate at the very good level of 45.84 percent. The personality of physical education instructors was appropriate at the very good level of 59.79 percent. The 
materials, equipment, and facilities were also appropriate at good level at 51.70 percent and the measurement and evaluation were appropriate at good level of 53.66 percent (see Figure 3d).

8) The opinions of KMUTT students towards teaching Physical Education in the sport of basketball as a whole, the purpose of physical education course is appropriate at the very good level of 62.31 percent. The subject matter and curriculum for Physical Education was appropriate at the very good level of 41.14 percent and the teaching methods, teaching and learning activities were appropriate at the very good level of $51.90 \%$. The personalities of Physical Education instructors were appropriate at the very good level at 63.04 percent. The factors of materials, equipment, and facilities are appropriate at good level for 42.66 percent and in the measurement and evaluation were appropriate at the very good level at 49.93 percent (see Figure 3e).
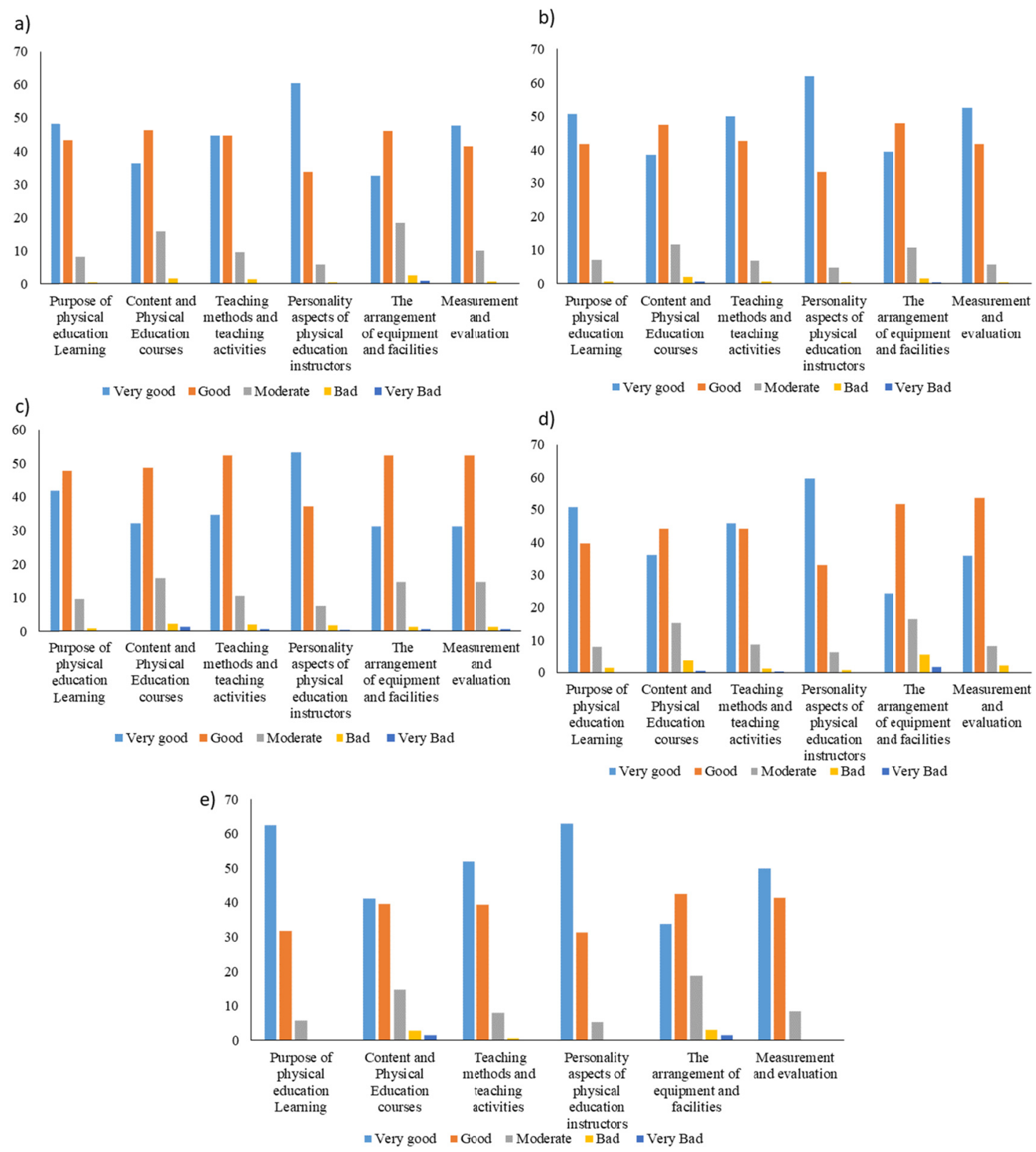

Figure 3. Teaching and learning of physical education in the sports; a) badminton, b) table tennis, c) dancing, d) tennis, and e) basketball

\section{Discussion}

The highest percentage for the overall development of teaching Physical Education in the personalities of Physical 
Education instructors and the measurement and evaluation criteria had the lowest percentage. However, the course content and curriculum were at a minimum percentage for male students, while the teaching methods and activities were higher among female students because of the increased interest of male students in activities rather than the content, which corresponds with gender behavior. For sports such as badminton, table tennis, dance, tennis and basketball, the personality factors of the instructor were still the most important, such as being a role model and motivating people to take part in student activities at university even though the students concentrated on classroom learning.

Their opinions on the purpose of physical education overall was at the highest level. This may be because most students believe that knowledge and understanding of Physical Education helps to safely enhance health, personality and movement skills. Also, knowing how to exercise properly allows students to see the importance of physical education because it is important and necessary for everyone. This knowledge can be applied in daily life to develop the mind, emotions and society and therefore students can see the value of the subject.

Overall, opinions on the subject matter and curriculum of Physical Education were at good level. This may be because most students believe that subject and course content have clear objectives, which enable students to gain direct and indirect experience of the curriculum. The knowledge of how to take care of themselves both physically and mentally, which is useful in terms of applying knowledge in daily life. This is consistent with Suriyachan (2007) who claimed that the course is the experience gathered all of the categories in order to transfer it to the students to experience it fully. The aim of the learners with the qualifications, knowledge and ability required by the instructors.

The curriculum is one of the most important influences on the participation of young people in Physical Education and there is evidence to suggest that positive attitudes (Dismore \& Bailey, 2010) There is also evidence to suggest that young people appreciate opportunities to co-construct their physical education curriculum with peers and teachers, such that their opinions inform curriculum development (Oliver, Hamzeh, \& McCaughtry, 2009). Student input in curriculum design may lead to a more student-centered and dynamic curriculum. Also, determining the needs of the students and interests is the initial step to modifying a curriculum in order to offer activities that provide students with meaningful experiences. When students select these activities, they were more likely to participate in Physical Education, and the activities and the curriculum were more meaningful from the perspectives of students (El-Sherif, 2013).

The opinions of the teaching methods and teaching and learning activities were at good level as a whole and included a variety of methods to choose the most appropriate way. The teaching blocks were easy to understand. In each aspect of teaching and learning, there was a clarification of the objectives to help learners to understand before starting learning. They also explained and demonstrated the skills and allow the students to perform correctly. Furthermore, the instructors also have to deal with the issue of competition in the class, such as enabling learners to have experience with problem-solving, understanding winning and losing, forgiveness and creating unity.

The enjoyment of physical education is at times is linked to changes in the learning environment and the context that physical education offers in comparison to classroom subjects, with young people reporting that they enjoy getting out of the classroom and moving about (Smith \& Parr, 2007).

However, Smith and Parr (2007) warned that it is not necessarily the kinds of sports and activities that are provided as part of the Physical Education curriculum that is of particular concern for students, but rather the range and the ways in which these activities are provided. However, the attributes of a teacher or coach should not be underestimated. Young people have a great deal to say about their learning experiences and they valued opportunities to contribute to the development of Physical Education and sports programs.

Their opinions on the personalities of Physical Education instructors in overall were at the very good level, which may be because learners can see how the personalities of the teacher had good qualities in the opinions of the learners (Yensabay, Suthiphan, \& Lewan, 2009) stated that Physical Education teachers have both efficiency and good qualities, such as dedication to teaching, knowledge, good personalities, friendliness and good human relations. The factor of emotional stability, the ability to understand the differences between interested individuals and pride in their careers as leader and the unique properties required.

Physical Education teachers play a key role in determining the attitudes and feelings of young people towards Physical Education and sports. Young people identified a number of teacher attributes that encouraged positive relationships with the teacher and positive learning experiences (Multihull, Rivers, \& Aggleton, 2000). Young girls, in particular, reported definite and often negative opinions about Physical Education teachers, suggesting that they tended to spend more time with and gave more attention to the boys. 
Overall, opinions about the organization of materials, equipment and facilities were at a high level, probably because students could see that the sports equipment was sufficient, in good working condition and safe for use, and the school can be used during and after school hours. The sports field was proportional and suitable for the type of sports, which was in accordance with Yensabay et al. (2009), and the facilities differed from other subjects. Teachers and administrators must see the benefits and importance because if arranged appropriately, it will help the teacher to be more efficient. Also, the arrangement of materials and equipment was also necessary for teaching. It must be planned by a knowledgeable person and allowing the safe use of effective equipment.

Overall, comments on measurement and evaluation were at a high level. This is because students can see how the exam stimulates them to become more interested; identify their skill levels and their deficiencies. In order to develop skills and abilities for evaluation, that the scoring criteria are clear and fair, both theoretically and practically, and in accordance with the learned content which developed learners to assess the results of the development of the quality of learners to be successful. The students must be developed and make assessments according to the indicators to achieve learning standards, to reflect important competencies and the desirable characteristics of the learners, who are the main targets in the measurement and evaluation of learning at all levels. The measurement and evaluation of learning is a process of improving the quality of learners by using assessment results as data to show development. The progress and academic success of learners, as well as information useful for promoting learners develop their full potential.

For teachers and coaches, in order to plan and deliver a meaningful physical education curriculum or in a sporting context, it is essential to be prepared to respond to their particular learning needs. That is, once the needs of young people are established, they can identify what motivates them to take part in, consider the reality of and the impact of their involvement in physical activity in their everyday lives. There is a close connection between young people in terms of encouraging or discouraging participation in physical education and sports (Wright, MacDonald, \& Groom, 2003).

\section{Concluding Remarks}

Nevertheless, there is a question of whether or not the students involved in physical education really understood the skills based on the learning standard document and aspects of the curriculum. The effectiveness of the delivery and standard competency levels of teachers had a strong connection with curriculum implementation (De Vries, 2004; Graber, 2001; Lumpkin, 2002; Mosston \& Ashworth, 2002). The failure to understand the physical education curriculum will result in not delivering it effectively to students. It is well known that teachers are the most important factor in ensuring that the learning process is on the right track. Therefore, research results should be presented to the management. Instructors use these studies to use the research results to improve education management.

The teaching and learning activities were in accordance with their needs to be effective and be of the most benefit to instructors and students at KMUTT.

\section{References}

De Vries, L.A. (2004). Physical education and sport. Toward the Achievement of millennium development Goals (MDG). Asian Society for Physical Education and Sport in Proceedings: 3rd International Conference of Asian Society for Physical Education and Sport. Indonesia: Directorate General of Sport, Ministry of National Education, in co-operation with Indonesia University of Education (pp. 41-54), Bandung, Indonesia.

Dismore, H., \& Bailey, R. (2010). 'It's been a bit of a rocky start': Attitudes toward physical education following transition. Physical Education and Sport Pedagogy, 15(2), 175-191. https://doi.org/10.1080/17408980902813935

El-Sherif, J. L. (2014). Student voice: Student choice and participation in physical education. Strategies, 27(5), 8-11. https://doi.org/10.1080/08924562.2014.938875

Graber, K. C. (2001). Research on teaching in physical education. In V. Richardson (Ed.), Handbook of research on teaching (4th ed.) (pp. 491-519). Washington: Columbia.

Lohaphaiboonkun, P. (2011). Survey on the opinions of the use for physical education curriculum. Journal of Human and Social Sciences, 2(1), 100-110.

Lumpkin, A. (2002). Introduction to physical education, exercise science, and sport studies (5th ed.). USA: McGraw-Hill.

Mosston, M., \& Ashworth, S. (2002). Teaching physical education (5th ed.). San Francisco: Benjamin Cumm. 
Mulvihill, C., Rivers, K., \& Aggleton, P. (2000). Views of young people towards physical activity: Determinants

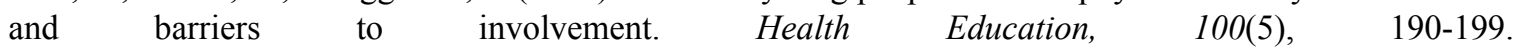
https://doi.org/10.1108/09654280010343555

National Association for Sport and Physical Education. (2012). Instructional framework for fitness education in physical education. Guidance document. Reston: Virginia.

Office of the Higher Education Commission. (2006). National Qualifications Framework for Higher Education in Thailand Implementation Handbook. Retrieved from http://www.mua.go.th/users/tqf-hed/news/FilesNews/FilesNews8/NQF-HEd.pdf

Oliver, K. L., Hamzeh, M., \& McCaughtry, N. (2009). Girly girls can play games Co-creating a curriculum of possibilities with 5th grade girls. Journal of Teaching in Physical Education, 28(1), 90-110. https://doi.org/10.1123/jtpe.28.1.90

Oudat, M., Bader, F., \& Khasawneh, A. (2009). Analytical studies for challenges which face physical education teacher in Jordanian public primary school. Scientific Journal of Physical Education and Sport, 37, 21-36.

Poonsri, W. (2008). A Study on the state of learning and teaching problems for physical education of the schools in central western region. Research reports and academic services, Faculty of Education and Development Sciences, Bangkok, Thailand: Kasetsart University Kamphaeng Saen Campus.

Robinson, L. E., \& Goodway, J. D. (2009). Instructional climates in preschool children who are at risk. Part I: Object-control skill development. Research Quarterly for Exercise and Sport, 80(3), 533-542. https://doi.org/10.1080/02701367.2009.10599591

Rodmunkong, T., \& Wannapiroon, P. (2013). The Design of Cloud Computing Management Information System Accordance with Thai Qualifications Framework for Higher Education. International Journal of e-Education, e-Business, e-Management and e-Learning, 3(3), 214-218. https://doi.org/10.7763/IJEEEE.2013.V3.226

Sallis, J. F., McKenzie, T. L., Beets, M. W., Beighle, A., Erwin, H., \& Lee, S. (2012). Physical education's role in public health: Steps forward and backward over 20 years and HOPE for the future. Research quarterly for exercise and sport, 83(2), 125-35. https://doi.org/10.1080/02701367.2012.10599842

Sinlarat, P., Theerapijit, S., \& Chaodamrong, W. (2009). National Qualifications Framework for Higher Education in Thailand from research to practice (2nd ed.). Bangkok, Thailand: Chulalongkorn University.

Smith, A., \& Parr, M. (2007). Young people's views on the nature and purposes of physical education: A sociological analysis. Sport, Education and Society, 12(1), 37-58. https://doi.org/10.1080/13573320601081526

Suriyachan, C. (2007). Real situation and expectation for provide teaching and learning of teachers and students in physical education institutions. Chiang Mai, Thailand: Institute of Physical Education Chiang Mai Campus.

The Ministry of Tourism and Sports. (2017-2021). The Sixth National Sports Development Plan. Bangkok, Thailand.

Wright, J., Macdonald, D., \& Groom, L. (2003). Physical activity and young people: beyond participation. Sport, Education and Society, 8(1), 17-33. https://doi.org/10.1080/1357332032000050042

Yensabay, C., Suthiphan, W., \& Lewan, N. (2009). The actual and desirable characteristics of physical education teachers according to the opinions of administrators and elementary school teachers under the Chonburi educational service area in academic. Journal of faculty of physical education, 14(1), 138-149. Retrieved from http://opacdb02.dpu.ac.th/cgi-bin/koha/opac-detail.pl?biblionumber=88250

\section{Copyrights}

Copyright for this article is retained by the author(s), with first publication rights granted to the journal.

This is an open-access article distributed under the terms and conditions of the Creative Commons Attribution license (http://creativecommons.org/licenses/by/4.0/). 